\title{
A VERTICALLY INTEGRATED UNDERGRADUATE PROJECT WITH REAL LIFE IMPACT: MONARCH ROUTE
}

\author{
Cuevas-Cancino $\mathrm{M}^{*}$, Peña-Becerril $\mathrm{M}$ and Camacho-Zuñiga $\mathrm{C}$ \\ School of Engineering and Sciences, Tecnologico de Monterrey, Mexico
}

\begin{abstract}
Monarch Route was a university award-winning project, having won the Premios Latinoamerica Verde in 2018. The project followed a research-based methodology and implemented a vertically integrated collaboration which included 181 undergraduate students; the entire student body enrolled in the Sustainable Development Engineering course of the Tec de Monterrey, Campus Santa Fe, in 2017. It was conducted in conjunction with the Fundación Nacional para la Conservación del Hábitat Boscoso de la Mariposa Monarca A.C. (FUNACOMM) so as to stop and revert the extinction of the monarch butterfly and at the same time promote benefits for the rural communities found throughout the migratory route of this species. The purpose of this work is to inspire the academic community to design successful projects which develop transverse and disciplinary competences. The project answered the following research question: What are the learning outcomes from participating in a project with real life impacts, working in a vertical and horizontal collaboration system? Using a mixed methodology, we describe the details of the implementation and learning outcomes. The Monarch Route project intrinsically motivated the students since it allowed them to collaborate, vertically and horizontally, in a socially relevant project, as well as having the choice and control over their education. By means of a text analysis of 22 final remarks of participating students, it was evident that they were able to recognize environmental, conservation and sustainable development problems and analyze their impact, in addition to being aware of the social aspects associated to them, and above all, recognize the link of these type of projects with their professional life and their social commitment to Mexico.
\end{abstract}

Keywords: vertically integrated project, self-regulated learning, Research-based methodology, text analysis, sustainability, higher education, educational innovation

\section{Introduction}

Monarch Route (MR) was an award-winning university project in 2018. It followed a research-based methodology and implemented a vertically integrated collaboration which included 181 undergraduate students the entire student body enrolled in the Sustainable Development Engineering program of the Tecnologico de Monterrey, Campus Santa Fe, in 2017. It was conducted in conjunction with the Fundación Nacional para la Conservación del Hábitat Boscoso de la Mariposa Monarca A.C. (FUNACOMM) to stop and revert the extinction of the monarch butterfly and, at the same time, promote benefits for the rural communities found throughout the migratory route of this species.

The purpose of this work is to inspire the academic community to design successful projects which develop transverse and disciplinary competences. This research answered the following question: 
What are the learning outcomes from participating in a project with real life impacts, working in a vertical and horizontal collaboration system?

\section{Research-based instruction}

Research based learning (RBL) is a teaching strategy which, according to the Boyer Commission on Educating Undergraduates in the Research University (1998) takes the student from a traditional passive learning to a leading role in what is to come. The student goes from being the receiver of knowledge to becoming a promoter and producer of it. This change takes place gradually over time as a result of RBL since it allows the student to learn by means of discovery until they are able to generate and transfer knowledge by themselves.

Among the competences developed by RBL we can identify open-mindedness, creative and critical thinking, research strategies, information analysis and information source valuation. To obtain these the instructor must design activities that allow the student to identify, analyse and solve problems (Boyer, 1998). In addition, the relationship between research and teaching generates immediate learning benefits in students due to their mutual complementarity (López-Gómez, 2015; Nehme 2012).

The four RBL strategies which foster the motivation for learning in students are:

- Choice: by giving students the opportunity to choose and follow their choices, they own the learning process. In addition, having a choice has been related to an increase in effort, quality of performance and probability of finishing the project. Therefore, choice is related to a successful learning process.

- Challenge: by challenging students with exacting activities, even those beyond what they believe they can achieve, an increase in student involvement is attained. This must be managed carefully since a well-defined challenge is a stimulus and by solving it, students feel a growing satisfaction of being more and more competent. However, if the difficulty is too high, even unreachable, then students could lose all interest.

- Collaboration: human beings are sociable by nature and, working with others motivates them to learn more. When interacting, students learn by discussing, clarifying ideas, and getting feedback; that is, they begin to build knowledge together. Furthermore, collaboration is more successful when students develop parallel and/or complementary activities which they identify as relevant to the situation.

- Control: when students self-manage their learning, they are more involved in the process, they become more receptive and honest about their work, performance, and abilities, even to the point of recognizing their mistakes and being more resilient to failure.

\section{Background}

There were 181 participants in the MR project, all of which were Engineering in Sustainable Development students at the Tecnologico de Monterrey, Campus Santa Fe. They all belonged to different semesters and subjects and worked in close collaboration during the semesters of AugustDecember 2017 and January-May 2018. 
MR was proposed as a RBL project with an innovative implementation due to its vertically and horizontally integrated collaboration, its social relevance and its interaction with a non-governmental organization (NGO). During a single initial general session, the project was presented to all the participants, assigning objectives according to the different years (i.e. freshmen, juniors, sophomores and seniors). FUNACOMM, an NGO dedicated to the conservation of the monarch butterfly, collaborated with the undergraduates, bringing to MR real life impact and applications. During the year that the project lasted, the students worked in teams within their classes and at the same time in collaboration with other teams in different classes and semesters.

The collaboration interactions are shown in Table 1 (see below). Here the method of collaboration among the students of each class and semester is described. The hand-in dates, both of partial as well as final project hand-ins, were dependent on the collaboration between classes and semesters. In other words, the students from different classes and semesters came to an agreement among themselves and established the dates.

Table 1: The implementation of the MR Project with 181 students in seven groups from five different classes and their respective hand ins.

\begin{tabular}{|c|c|c|c|c|}
\hline Semester & Class & $\begin{array}{l}\text { Number of } \\
\text { students }\end{array}$ & $\begin{array}{l}\text { Collaborating } \\
\text { semesters }\end{array}$ & Final project \\
\hline $1^{\text {st }}$ & $\begin{array}{l}\text { Climate Change } \\
\text { and Energy Use }\end{array}$ & 33 & $6^{\text {th }}$ & $\begin{array}{l}\text { Report on the impacts of climate } \\
\text { change on the monarch butterfly } \\
\text { route }\end{array}$ \\
\hline $2^{\text {nd }}$ & $\begin{array}{l}\text { Ecosystems and } \\
\text { Biodiversity }\end{array}$ & $\begin{array}{l}\text { Group 1: } 20 \\
\text { Group 2: } 32\end{array}$ & $1^{\text {st }} / 6^{\text {th }}$ & $\begin{array}{l}\text { Environmental agenda based on } \\
\text { the Sustainable Development } \\
\text { Goals (SDG) for the conservation } \\
\text { of the monarch butterfly }\end{array}$ \\
\hline $3^{\text {rd }}$ & $\begin{array}{l}\text { Sustainable } \\
\text { Development } \\
\text { Principles }\end{array}$ & $\begin{array}{l}\text { Group 1: } 25 \\
\text { Group 2: } 25\end{array}$ & $1^{\text {st }} / 2^{\text {nd }} / 9^{\text {th }}$ & $\begin{array}{l}\text { Create an environmental teaching } \\
\text { resource based on the conservation } \\
\text { of the monarch butterfly (School } \\
\text { years: lower primary; upper } \\
\text { primary; middle school; high } \\
\text { school; adults) }\end{array}$ \\
\hline $6^{\text {th }}$ & $\begin{array}{l}\text { Natural Resource } \\
\text { Management and } \\
\text { Climate Change }\end{array}$ & 40 & $1^{\text {st }} / 2^{\text {nd }}$ & $\begin{array}{l}\text { Maps identifying possible } \\
\text { conservation areas in Mexico for } \\
\text { the conservation of the monarch } \\
\text { butterfly using information } \\
\text { provided by } 1^{\text {st }} \text { semester students }\end{array}$ \\
\hline $9^{\text {th }}$ & $\begin{array}{l}\text { Sustainable } \\
\text { Development } \\
\text { Integrating Project }\end{array}$ & 6 & $1^{\text {st }} / 2^{\text {nd }} / 3^{\text {rd }}$ & $\begin{array}{l}\text { Report and presentation: a traffic } \\
\text { light system identifying the } \\
\text { degradation and habitat evaluation } \\
\text { of the monarch butterfly } \\
\text { Creation of an APP: PASALO } \\
\text { used for the monitoring of the } \\
\text { monarch butterfly route in Mexico }\end{array}$ \\
\hline
\end{tabular}

\section{Method}

To analyse the learning outcomes of the MR project an exploratory research was conducted using a mixed methodology. 
The information was gathered two months after the end of the project using a survey and written final remarks, both optional. The survey, applied via Google Forms, was written in Spanish and included nine closed questions and three open ones; forty-five students answered the survey giving it an $87 \%$ reliability.

Regarding the final remarks, the students were asked to write a letter to their classmates following this instruction: "Write a letter to the incoming classes telling them about the Monarch Route project". We obtained twenty-two letters and analysed them using a Text and Sentiment Analysis (TSA) according to the model shown in Figure 1 (Okove.K, Arona-Palacios. A, Camacho-Zuñiga.C, Hammout.N, Nakamura.E, Hosseini.S, 2020; Rojas-Castro, P. 2017).
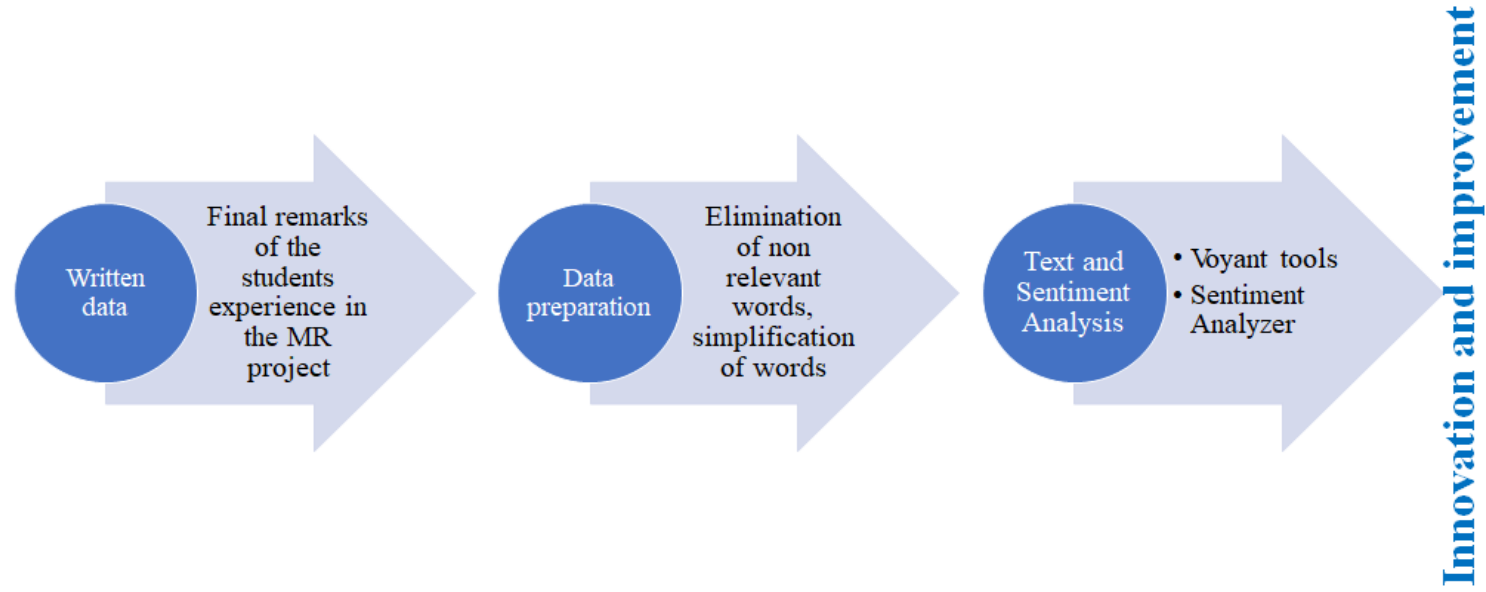

Figure 1: Model to perform a Text and Sentiment Analysis on the twenty-two final remarks provided by the participating students.

The text analysis was performed in Spanish using Voyant Tools (Sinclair and Rockwell, 2016), while for the sentiment analysis the texts were translated to English and the Sentiment Analyzer tool (Soper, 2006) was used.

\section{Results and discussion}

By participating in MR the students perceived different learning outcomes in regards to both transverse competences (collaboration, citizenship, communication, critical thinking) as well as disciplinary competences (subject matter).

The student's perception regarding MR can be seen in Figure 2, which shows the most significant learning outcomes. Citizenship was the most mentioned competence, while project organization was the least mentioned competence. 


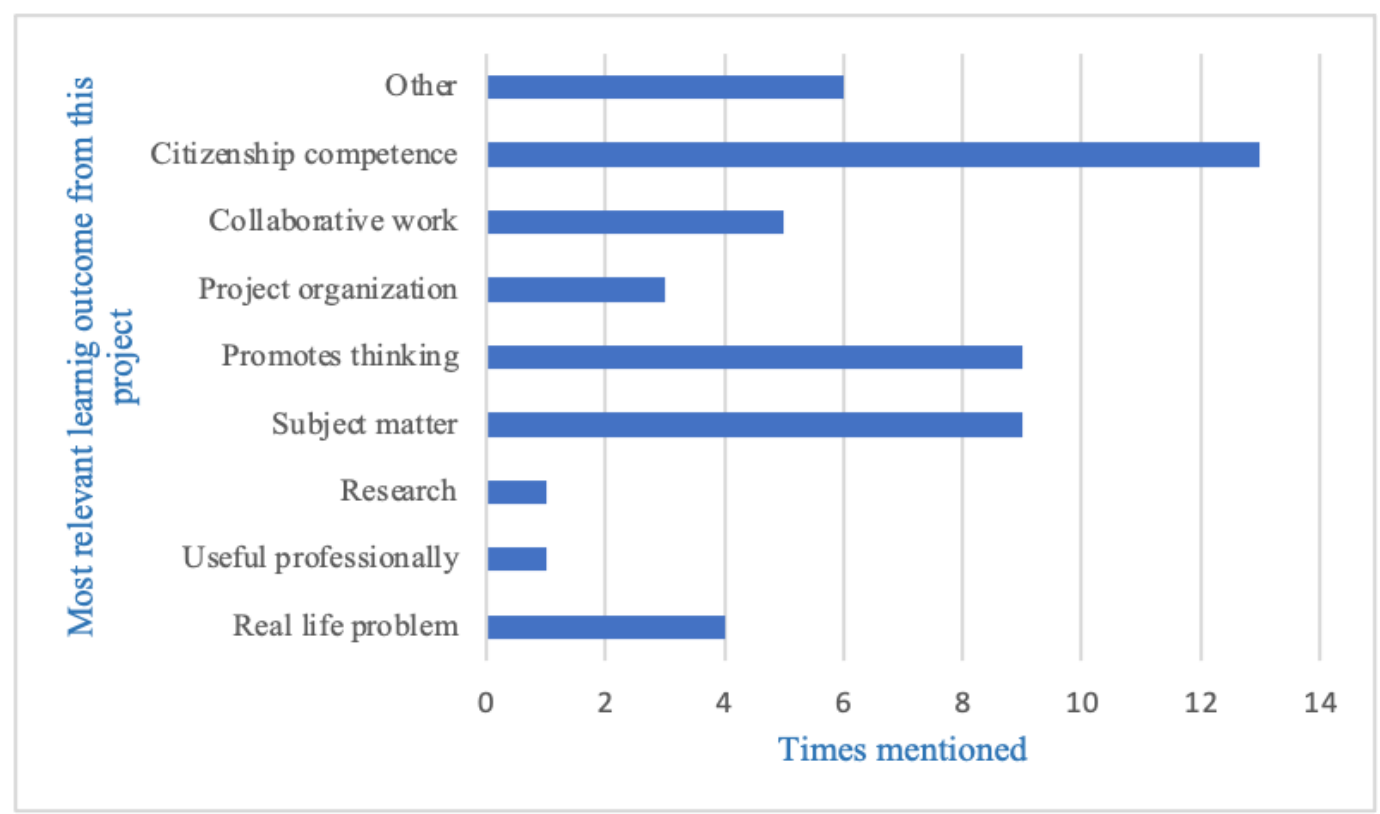

Figure 2: Students answers to the instructions: "Define the most relevant learning outcome obtained from this project in a sentence or phrase”, categorized according to the authors interpretation

In other words, MR was recognized by the students as a relevant issue; both, from a professional point of view, a disciplinary competence such as sustainability, as well as, from transverse competences such as human spirit, ethics and citizenship. Figure 3 reports the undergraduates' competences that were developed by working in MR according to the students own perception.

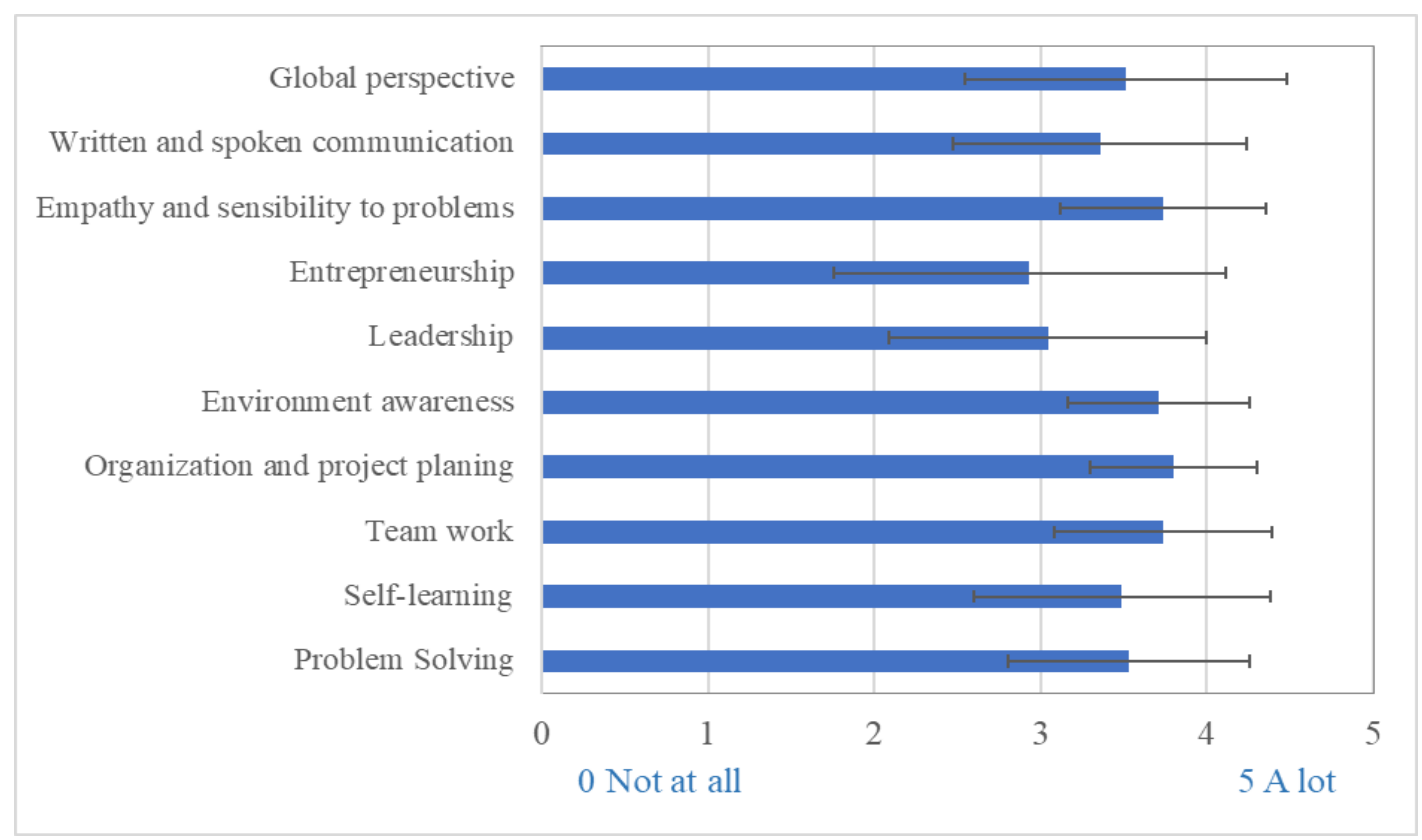

Figure 3: Students answers to the question: "How much did the MR project contribute to the development of which competences and/or abilities?".

The learning outcomes of MR were significant and identified by the students as transferable to other scenarios, as can be seen in Table 2 . One of the challenges of education is the difficulty faced by the students when transferring what they have learned in the classroom to new situations, however MR overcame this obstacle. 
Table 2: Mean and standard deviation of three questions from the survey applied to students in a Likert scale, from 0 to 4, where 4 is considerably.

\begin{tabular}{lll}
\hline Question & Mean & Standard deviation \\
\hline $\begin{array}{l}\text { How much of what you learned in this } \\
\text { project can be applied to other projects? }\end{array}$ & 3.18 & 0.57 \\
\hline $\begin{array}{l}\text { How much would you recommend this } \\
\text { project? }\end{array}$ & 3.6 & 0.33 \\
\hline $\begin{array}{l}\text { How useful was this project to the } \\
\text { community? }\end{array}$ & 3.44 & 0.69 \\
\hline
\end{tabular}

MR was a motivating project for undergraduates from various perspectives. Motivation is fundamental for a significant self-managed learning outcome; a motivated student maintains an interest and is committed to the work, ensuring the achievement of the objectives set forth in the project. MR managed to keep participants motivated for an entire year, seeking the appropriation of the project by the students due to the need for the conservation of the monarch butterfly. Analysing the characteristics of MR from Chase \& Laufenberg's perspective, we identified the following:

- MR gave students the opportunity to choose. The implementation instructions of the project were ample, fixing a clear and well delineated objective, but without specifying the procedure nor the means. For example: the 3rd-semester teams were asked to generate any teaching resource as long as it was related to environmental education, for a specific educational level, and fostered the conservation of the monarch butterfly.

- MR presented the students with an actual, global real-life challenge from the point of view of several different classes and semesters due to its collaboration structure, the link with the social context surrounding the issue, and because of its professional relevance.

- MR allowed a for vertically and horizontally integrated collaboration. This meant students had to work with both classmates from their own semester, from other semesters, as well as people in rural communities and the FUNACOMM.

- MR allowed students to take control of their learning process. As stated in the implementation (see Table 1), they were able to control the means and, in some cases, the final product so as to obtain the objective specified and the hand-in date.

In so far as a global evaluation of the project, over $95 \%$ of the students considered that it was useful for the community in addition to recommending it to others (see Table 2). The reasons given for this recommendation are shown in Figure 4, where the subject area and the citizenship competence are the most mentioned. 


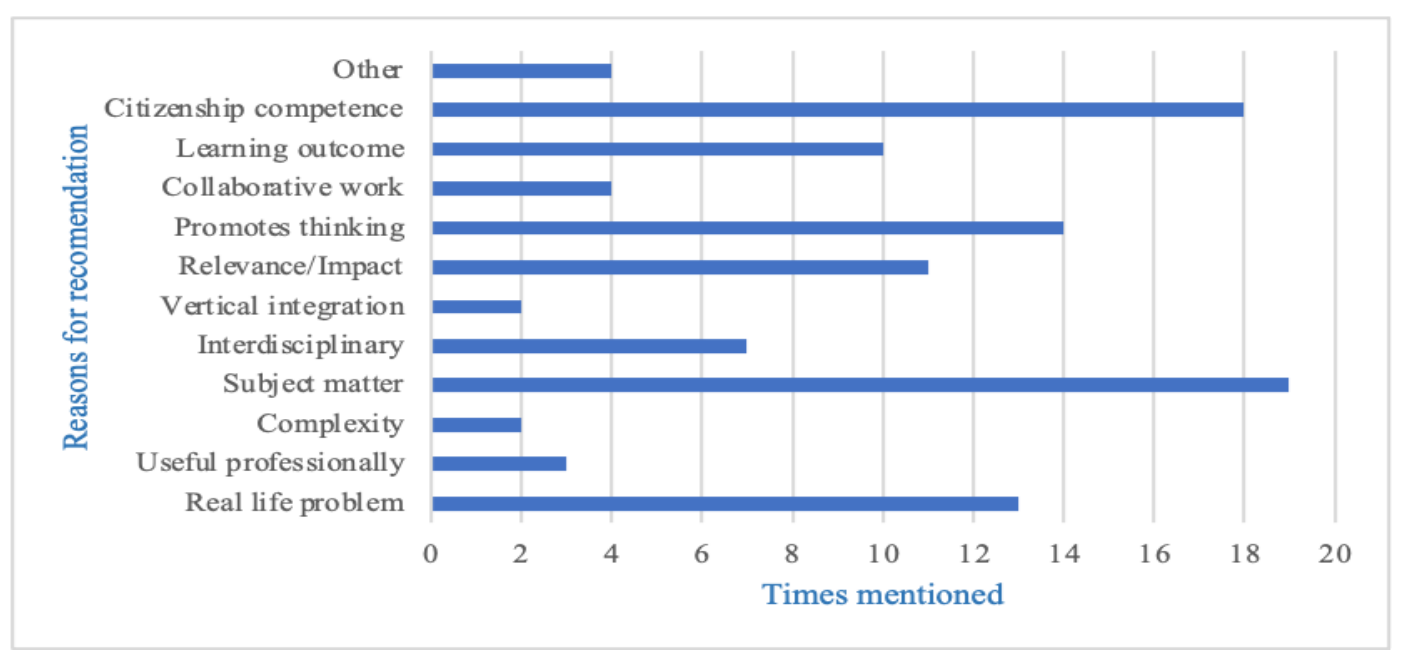

Figure 4: Students answers to the open question: "Why would you recommend this project?", categorized according to the authors interpretation.

Concerning the text analysis, for each final remark the average sentence length and the word count was registered, including vocabulary richness and emotional valence. The final remarks had an average of 243 words, a vocabulary richness of $56 \%$ and an average sentence length of 31 words. Table 3 presents the results of this analysis.

Table 3: Text analysis results: word count, vocabulary richness, emotional valence of the 22 final remarks provided by students who participated in MR.

\begin{tabular}{|c|c|c|c|c|c|}
\hline Student & Words & Type & Proportion & Words/sentence & Sentiment \\
\hline 1 & 276 & 137 & 50 & 34.5 & 59 \\
\hline 2 & 221 & 130 & 59 & 36.8 & 48.6 \\
\hline 3 & 362 & 192 & 53 & 27.8 & 97.3 \\
\hline 4 & 112 & 74 & 66 & 22.4 & 99.4 \\
\hline 5 & 165 & 105 & 64 & 55 & -99.8 \\
\hline 6 & 126 & 75 & 60 & 25.2 & 100 \\
\hline 7 & 150 & 89 & 59 & 25 & -89.2 \\
\hline 8 & 244 & 120 & 49 & 30.5 & 46 \\
\hline 9 & 374 & 187 & 50 & 34 & 9.4 \\
\hline 10 & 115 & 77 & 67 & 28.8 & -100 \\
\hline 11 & 157 & 94 & 60 & 19.6 & 79.5 \\
\hline 12 & 331 & 175 & 53 & 25.5 & 94.5 \\
\hline 13 & 225 & 130 & 58 & 28.1 & 100 \\
\hline 14 & 179 & 106 & 59 & 17.9 & -80 \\
\hline 15 & 291 & 165 & 57 & 26.5 & -60.9 \\
\hline 16 & 220 & 119 & 54 & 55 & -84.2 \\
\hline 17 & 286 & 162 & 57 & 23.8 & -60.4 \\
\hline 18 & 303 & 170 & 56 & 60.6 & 89.2 \\
\hline 19 & 550 & 282 & 51 & 30.6 & -61.6 \\
\hline 20 & 162 & 91 & 56 & 32.4 & 97.8 \\
\hline 21 & 290 & 143 & 49 & 32.2 & 35.6 \\
\hline 22 & 215 & 132 & 61 & 19.5 & -71.2 \\
\hline
\end{tabular}


Figure 5 shows the word cloud of the twenty-five most frequently mentioned words in the student's final remarks on their experience with MR; each of the terms is represented proportionally to its frequency. The most mentioned words were "project", "monarch", "butterfly", "route" and "ours" with 96, 70, 55, 41 and 40 mentions respectively. From the four most mentioned words by the participants, we can identify the challenge of the project, which was to strengthen a project related to the monarch butterfly migration route. The subsequent word, "ours", is a central point in the success of the MR project. In terms of RBL, this brings the students closer to a real-life problem and the competences obtained, in addition to intensifying the search for solutions and at the same time it allows the students to acquire the competences needed for their future professional life.

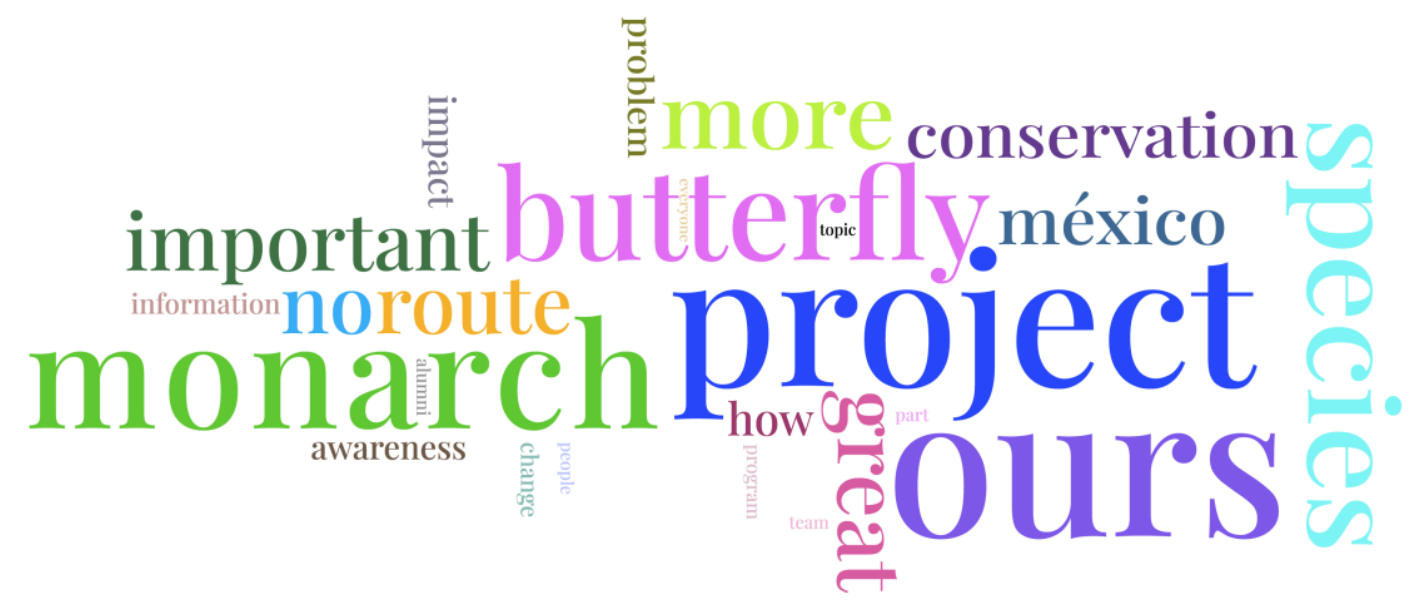

Figure 5: Word cloud of the 25 most frequently mentioned words in the final remarks of the students experience in the MR project.

Figure 6 is a diagram showing the eighteen most mentioned words and their interrelationship. We can observe the different trajectories, reflecting the articulation of the concepts mentioned by the participants, which are not only solid, but also consistent and progressive. Regarding the nodes, subgroups can be identified, related to the disciplinary and transverse competences. Among the disciplinary ones are: "ours" and "Mexico", which involve the citizenship competence. Another relevant node is generated around the word "how", which shows the full capabilities of the students to generate, by themselves, knowledge and competences. 


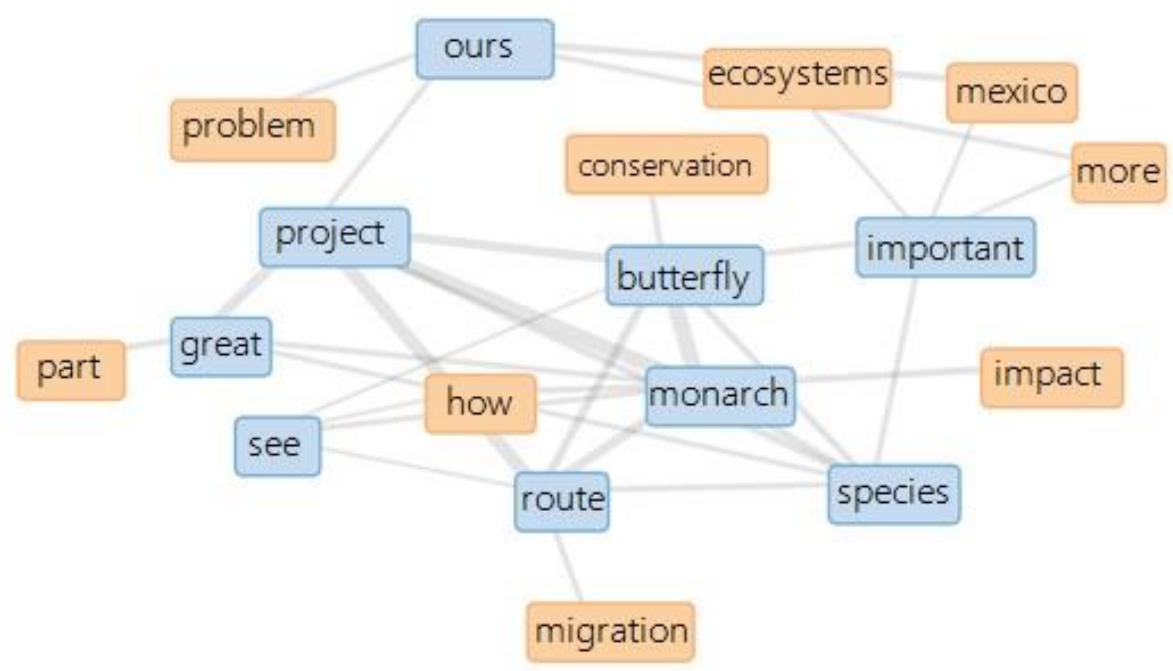

Figure 6: The interrelationship of the 18 most mentioned words in the final remarks of the students experience in the MR project.

With regards to the correlation of the terms, Table 4 states the different paired words mentioned. For simplicity, of a total of 5354 analysed words, only 30 pairs are shown, grouped according to their subject matter: rows 1 and 2 are collaborative work; rows 3 to 6 relate to the relevance of RBL; rows 7 to 18 are transverse competences and rows 19 to 30 are disciplinary competences. Concerning the relevance of the RBL methodology, the competences mentioned by Boyer (1998) of information analysis and source valuation are explicitly seen in the mentioned pairs (rows 3-6). The references for rows 7 to 18 and 19 to 30 show the effectiveness of this methodology for the achievement of the project's objectives and the transverse and disciplinary competences.

Table 4: Word pairs mentioned in sequence together with their correlations made by the twenty-two students who participated in MR and the highest correlation coefficients.

\begin{tabular}{llll}
\hline Row number & \multicolumn{2}{l}{ Word pairs mentioned in sequence } & $\begin{array}{l}\text { Correlation } \\
\text { coefficients }\end{array}$ \\
\hline 1 & activity & collaborate & 0.9883 \\
\hline 2 & collaborate & primary & 0.9883 \\
\hline 3 & quality & research & 0.9874 \\
\hline 4 & trustworthy & research & 0.9874 \\
\hline 5 & sources & research & 0.9874 \\
\hline 7 & outside & research & 0.9874 \\
\hline 8 & establish & reserve & 0.9688 \\
\hline 9 & management & reserve & 0.9688 \\
\hline 10 & establish & town & 0.9688 \\
\hline 11 & management & town & 0.9688 \\
\hline 12 & establish & zone & 0.9688 \\
\hline 13 & management & zone & 0.9688 \\
\hline 14 & chose & establish & 0.9688 \\
\hline 15 & chose & management & 0.9688 \\
\hline & establish & important & 0.9688 \\
\hline
\end{tabular}




\begin{tabular}{llll}
\hline 16 & establish & professor & 0.9688 \\
\hline 17 & establish & objectives & 0.9688 \\
\hline 18 & establish & area & 0.9688 \\
\hline 20 & knowledge & ecosystem & 0.9684 \\
\hline 21 & learn & care & 0.9684 \\
\hline 22 & learn & die & 0.9684 \\
\hline 23 & learn & opportunity & 0.9684 \\
\hline 24 & aware & care & 0.9456 \\
\hline 25 & aware & economy & 0.9456 \\
\hline 27 & aware & primary & 0.9456 \\
\hline 28 & citizens & ecosystem & 0.9444 \\
\hline 29 & adults & ecosystem & 0.9444 \\
\hline 30 & app & ecosystem & 0.9444 \\
\hline
\end{tabular}

The emotional valence of the undergraduates' final remarks about MR was positive, with an average of 11.3 and a standard deviation of 80.5. The software used for the sentiment analysis assigns valences on a scale of -100 to 100 . Table 5 shows the valences assigned to some students' final remarks across the complete scale, as well as including excerpts of the student's remarks exemplifying the emotional valence for both positive and negative values. Albeit the amplitude of the range illustrates how this artificial intelligence tool is still evolving, we can observe, using the example of student 17 , how a negative valence can be associated to the students' perception of the complexity and seriousness of the extinction of the monarch butterfly. With regard to the highly positive valences (students 6 and 13), their focus on the project achievements and their learning outcomes can be perceived. Finally, the close to zero average obtained, shows the students objectivity, even though a slightly positive tendency can be seen.

Table 5: Most significant emotional valences exemplified with the text written by the students that participated in MR.

\begin{tabular}{lll}
\hline Student & Emotional valence & Text exemplifying the reported sentiment \\
\hline 1 & 59 & $\begin{array}{l}\text { The project is an incredible way to help the environment in the } \\
\text { north American region and the Mexican population, since, } \\
\text { besides being an ecosystem conservation tool, it helps us } \\
\text { Mexicans to have more knowledge on the subject and allows us } \\
\text { to perform significant actions which contribute to reducing the } \\
\text { negative impacts to the environment that we cause day to day. }\end{array}$ \\
& $\begin{array}{l}\text { The project not only helped us understand more about the } \\
\text { species, but we also learned about the protocols our country has } \\
\end{array}$ & $\begin{array}{l}\text { for the conservation of it. Learning about some of the laws that } \\
\text { Mexico has for ecological conservation is very useful for future } \\
\text { projects we may have in mind. }\end{array}$ \\
\hline 9 & $\begin{array}{l}\text { I consider that it is key to know a species, understand it, where it } \\
\text { lives, the importance it has in our ecosystems, etc. so that people } \\
\text { naturally want to conserve it, and not only the butterfly, but any } \\
\text { species. We have to have or create a link so that we humans } \\
\text { want to help maintain or even increase the number of } \\
\text { individuals of a species. }\end{array}$ \\
\hline
\end{tabular}




\begin{tabular}{lll}
\hline $10-100$ & $\begin{array}{l}\text { In my first semester I worked on a project to develop a plan to } \\
\text { protect the monarch butterfly. We worked in teams to decide } \\
\text { which were the most viable solutions and that could be } \\
\text { implemented in Mexico. }\end{array}$ \\
\hline $13 \quad \begin{array}{l}\text { The monarch route project allowed us, from a school project, to } \\
\text { collaborate, transcend and aid in the objective to save the } \\
\text { monarch butterfly. The most important part was that each } \\
\text { student of each semester was able to contribute their work so } \\
\text { that the project could come together and achieve great results. }\end{array}$ \\
$\begin{array}{ll}\text { Deforestation influences the death of the butterfly since they } \\
\text { have nowhere to rest or eat. Because of this, for the Ecosystems } \\
\text { and Biodiversity class, we did a project to monitor the route the } \\
\text { monarchs follow when they migrate and we researched their } \\
\text { main causes of death so as to prevent them from dying and help } \\
\text { them survive. }\end{array}$ \\
\hline
\end{tabular}

\section{Conclusions}

The Monarch Route (MR) project was a success as a motivator for student learning was shown in the learning outcomes and transference perceptions of the students, as well as being highly recommended by them. It was an innovative project from its inception due to its subject matter, implementation and impact on the student's reality.

Regarding its implementation, MR characterized itself for being very flexible, both in the way students collaborated between classes and semesters, as in the dates and choice of final products with which to achieve its objectives. Its subject matter provided the students with a very relevant issue related to their professional field and a citizenship scope. In addition, MR impacted the environment and the issue directly since all the proposals were implemented and carried out by the FUNACOMM. All these characteristics coincide with those mentioned by Chase \& Laufenberg as being intrinsic learning motivators; meaning MR was a challenge which allowed students to collaborate, have a choice and control their own learning process. These characteristics must be considered by other professors as effective project design strategies.

It is important to mention that MR was limited in both the number of students as well as the variety of subject matter and study areas since it only focused on a specific issue. Therefore, we recommend that more projects like this be carried out for both different fields and academic majors.

The Text and Sentiment Analysis (TSA) is an innovative methodology used to analyse the ideas of students by means of word clouds, diagrams, emotional valences and word correlations. Using these, the scope of the Research Based Learning strategy in the identification and analysis of problems, creative and analytical thinking as well as information analysis and source valuation was confirmed. The TSA reflected the student's ability to form a broad overall picture of the challenge presented and for them, MR went beyond a school project; it included the conservation of a species, the understanding of a problem, the importance of its impact, all the social aspects associated with the issue and, above all, its relationship with their professional life and social commitment to Mexico.

\section{Acknowledgements}

The authors would like to acknowledge the financial support of Writing Lab, Institute for the Future of Education, Tecnologico de Monterrey, Mexico in the production of this work. 


\section{References}

Boyer Commission on Educating Undergraduates in the Research University (1998). Reinventing Undergraduate Education: A Blueprint for America's Research Universities. New York: State University of New York at Stony Brook.

Casanovas-Rubio, M. Ahearn, A. Ramos, G. y Popo-Ola, S. (2014) The research-teaching nexus: using a construction teaching event as a research tool. Innovations in Education and Teaching International , 53, pp 1-15.

Cuevas Cancino, M. de la O L., Peña Becerril, M. y Camacho Zuñiga, C. (2019) Las características de un proyecto exitoso de aprendizaje: Ruta Monarca. $6^{\circ}$ Congreso Internacional de Innovación Educativa CIIE, Monterrey N.L, México.

Delgado, P., (2019, May). Elección, desafío, colaboración y control: las grandes cualidades en la motivación intrínseca. Observatorio de innovación educativa del TEC de Monterrey. Retrieved from https://observatorio.tec.mx/edu-news/eleccion-desafio-colaboracion $\quad$-y-control-las-grandescualidades-en-la-motivacion-intrinseca

ElZomor, M.; Mann, C.; Doten-Snitker, K.; Parrish, K.; Chester, M. (2018). Leveraging Vertically Integrated Courses and Problem-Based Learning to Improve Students' Performance and Skills. Journal of Professional Issues in Engineering Education and Practice. 144(4).

Lopatto, D. (2007). Undergraduate Research Experiences Support Science Career Decisions and Active Learning. CBE—Life Sciences Education, 6(4), 297-306. https://doi.org/10.1187/cbe.07-060039

López-Gómez, E. (2015). Conectando investigación y docencia en la Universidad: Teaching research nexus. Revista Interuniversitaria, 22, pp $203-220$.

McBride , T.O.; DeGoede, K.; Fullerton, J. (2009) Sustainable engineering vertically-integrated project scheme in undergraduate engineering education. IEEE International Symposium on Sustainable Systems and Tecnology, Tempe, AZ, USA, pp. 1-6.

$\begin{array}{lllll}\text { Modelo Educativo } & \text { TEC21. } & \text { (2016). } & \text { Retrieved }\end{array}$ http://modelotec21.itesm.mx/files/folletomodelotec21.pdf

Nehme, M. (2012). The Nexus between Teaching and Research - Easier Said than Done. Legal Education Review , 22, pp 241-272, Available at SSRN: https://ssrn.com/abstract=2350571

Okoye.K,Arrona-Palacios.A,Camacho-Zuñiga. C, Hammout.N, Nakamura. E, Hosseini. S. Impact of Students Evaluation of Teaching: A Text Analysis of the Teachers Qualities by Gender. International Journal of Educational Technology in Higher Education. ISSN: 2365-9440 (In Press)

Oudeyer, P.-Y., Gottlieb, J., \& M. Lopes. (2016). Intrinsic motivation, curiosity, and learning. Progress in Brain Research, 229, pp. 257-284.

Rojas-Castro, P. (2017). Learning analytics. Una revisión de la literatura. Educación y Educadores, 20(1), 106-128

Savelsbergh, E.R., Prins, G.T., Rietbergen, C., Fechner, S., Vaessen, B.E., Draijer, J.M., \& Bakker, A. (2016). Effects of innovative science and mathematics teaching on student attitudes and achievement: A meta-analytic study. Educational Research Review, 19, pp. 158-172.

Sinclair, S. and Rockwell, G. (2016). Voyant Tools. Web. http://voyant-tools.org/.

Soper, D. (2006) Sentiment Analyzer. https://www.danielsoper.com/sentimentanalysis/default.aspx.

Snyder, S.D. (2002). Vertically integrated projects and the importance of organizational culture amongst the student body. International Journal of Engineering Education, 18(3), pp. 307-314. https://www.ijee.ie/articles/Vol18-3/ijee1204.pdf 
Strachan, S. M., Marshall, S., Murray, P., Coyle, E. J., \& Sonnenberg-Klein, J. (2019). Using Vertically Integrated Projects to embed research-based education for sustainable development in undergraduate curricula. International Journal of Sustainability in Higher Education, 20(8), pp. 1313-1328. https://doi.org/10.1108/ijshe-10-2018-0198 